\title{
Does hypothyroidism increase the risk of breast cancer: evidence from a meta- analysis
}

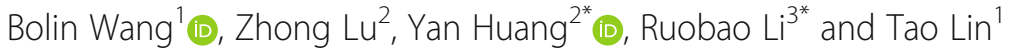

\begin{abstract}
Purpose: At present, the relationship between hypothyroidism and the risk of breast cancer is still inconclusive. This meta-analysis was used to systematically assess the relationship between hypothyroidism and breast cancer risk, and to assess whether thyroid hormone replacement therapy can increase breast cancer risk.

Methods: The relevant articles about hypothyroidism and the risk of breast cancer were obtained on the electronic database platform. Relevant data were extracted, and odd ratios (OR) with corresponding $95 \%$ confidence intervals (Cl) were merged using Stata SE 12.0 software.

Results: A total of 19 related studies were included in the meta-analysis, including 6 cohort studies and 13 casecontrol studies. The results show that hypothyroidism was not related to the risk of breast cancer (odd ratios $=0.90$, 95\% Cl 0.77-1.03). In the European subgroup, we observed that patients with hypothyroidism have a lower risk of breast cancer(odd ratios $=0.93,95 \% \mathrm{Cl}$ 0.88-0.99). Furthermore, no significant correlation was observed between thyroid hormone replacement therapy and the risk of breast cancer. (odd ratios $=0.87,95 \% \mathrm{Cl} 0.65-1.09$ ).

Conclusion: Hypothyroidism may reduce the risk of breast cancer in the European population, and no significant correlation was observed between hypothyroidism and breast cancer risk in non-European populations. Due to the limited number of studies included, more large-scale, high-quality, long-term prospective cohort studies are needed.
\end{abstract}

Keywords: Hypothyroidism, Thyroid hormone replacement therapy, Breast cancer, Meta-analysis

\section{Background}

As a global public health problem, breast cancer has an increasing incidence on a global scale [1]. According to the 2017 US cancer statistics, breast cancer has become the most common malignant tumour in women, with about 250,000 new cases each year, accounting for $30 \%$ of new malignant tumours in women [2]. Therefore, the identification of risk factors for breast cancer and the

\footnotetext{
*Correspondence: Yanhuangdr@163.com; Ruobaolidr@163.com

${ }^{2}$ Department of Oncology, Affiliated Hospital of Weifang Medical University, Weifang 261031, China

${ }^{3}$ School of Basic Medicine, Weifang Medical University, Weifang 261053, China

Full list of author information is available at the end of the article
}

adoption of effective early prevention and intervention measures are of great significance for patients with breast cancer.

The physiology and pathology of the breast are closely related to the endocrine of the body [3]. As the largest endocrine organ in the human body, the thyroid gland has specific regulation effects on various hormone levels and cell growth and development in the body, which brings new enlightenment to the research of breast cancer [4-6]. In 1976, Kapdi et al. first proposed that hypothyroidism maybe increase the risk of breast cancer [7]. Since then, many scholars have studied the relationship between hypothyroidism and the risk of breast

C C The Author(s). 2020 Open Access This article is licensed under a Creative Commons Attribution 4.0 International License, which permits use, sharing, adaptation, distribution and reproduction in any medium or format, as long as you give appropriate credit to the original author(s) and the source, provide a link to the Creative Commons licence, and indicate if changes were made. The images or other third party material in this article are included in the article's Creative Commons licence, unless indicated otherwise in a credit line to the material. If material is not included in the article's Creative Commons licence and your intended use is not permitted by statutory regulation or exceeds the permitted use, you will need to obtain permission directly from the copyright holder. To view a copy of this licence, visit http://creativecommons.org/licenses/by/4.0/ The Creative Commons Public Domain Dedication waiver (http://creativecommons.org/publicdomain/zero/1.0/) applies to the data made available in this article, unless otherwise stated in a credit line to the data. 
cancer. However, the relationship between the two diseases remains controversial [7-11]. Some studies have shown that hypothyroidism increases the risk of breast cancer [7-9]. Some studies have shown that hypothyroidism reduces the risk of breast cancer [10]. Besides, some studies have found no correlation between thyroid disease and breast cancer risk [11]. Therefore, whether hypothyroidism can increase the risk of breast cancer is worthy of further study.

Two meta-analyses have previously been studied for hypothyroidism and breast cancer risk $[11,12]$. Based on previous research, we have included more prospective studies and Asian population studies to assess the relationship between hypothyroidism and breast cancer risk systematically. Besides, the impact of thyroid hormone replacement therapy on breast cancer risk was explored in this meta-analysis.

\section{Methods}

\section{Search strategy}

Relevant clinical literature was extracted by systematic retrieval of PubMed (Medline), EMBASE, Springer, Web of Science, and Cochrane Library electronic databases up to date to October 2019. Our search strategy included terms for: "thyroid dysfunction" or "hypothyroidism" or "HT" and "thyroid diseases" or "breast cancer" or "BC" or "breast neoplasms" or "mammarmy cancer" and "risk" or "incidence". At the same time, we manually screened out the relevant potential literature in the references extracted.

\section{Inclusion and exclusion criteria}

1) The inclusion criteria:

2) Types of studies: Published studies exploring the relationship between hypothyroidism and breast cancer risk;

3) Subject: Female;

4) Exposure factors: Primary hypothyroidism, the diagnosis needs to be based on the detection of thyroid function;

5) Outcome indicators: the occurrence of primary breast cancer.

The exclusion criteria:

1) Non-primary hypothyroidism due to other causes;

2) Non observational studies;

3) Insufficient information was provided or no fulltext;

4) Unable to obtain full text or quality assessment of the literature;

5) Studies were repeated or publications overlapped.

\section{Data extraction and quality assessment}

Two researchers separately conducted literature screening, data extraction, and literature quality evaluation, and any differences could be resolved through discussion or a third inspector. Information secured from the enrolled literature included: first author's surname, year of publication, country of the population, sample size, follow-up time, and data on the relationship between hypothyroidism and the risk of breast cancer.

The Newcastle-Ottawa Scale (NOS) was used to assess the quality of the study from three aspects: cohort selection, cohort comparability, and outcome evaluation [13]. NOS scores of at least six were considered high-quality literature. Higher NOS scores showed higher literature quality.

\section{Statistical analysis}

All data analysis was performed using Stata12.0 software. Meta-analysis was performed according to the PRISMA guidelines. The OR and 95\%CI from included studies were treated with the combined effect size. After that, the heterogeneity test was conducted. When $P \geq 0.05$ or $\mathrm{I}^{2}<50 \%$ was performed, it mean that there was no apparent heterogeneity, and the fixed-effect model should be applied for a merger. When $P<0.05$ or $\mathrm{I}^{2} \geq 50 \%$ indicated high heterogeneity, the random-effect model was applied. Combined effect size, if OR $>1$ indicates that hypothyroidism is an unfavorable factor for breast cancer. If OR $<1$ is the opposite. Publication bias Begg funnel plot and Egger test linear regression test were used to research publication bias detection of the literature included. If $P<0.05$ indicates obvious publication bias.

\section{Results}

Process of study selection and description of qualified studies

A total of 2415 studies were identified on our online databases. After exclusion of duplicate references,129 articles were considered. After screening the abstract and title, 102 articles were excluded. After careful review of the full texts, 8 studies have been excluded because 5 of them did not provide relevant data, and 3 articles did not have full-text. Nineteen articles published between 1978 and 2019 met the inclusion criteria (Fig. 1).

A total of 367,416 samples from 19 studies involving were enrolled in this meta-analysis [4, 8-10, 14-28]. Six cohort studies and 13 case-control studies were included in the study. Twelve articles were studied in the European population, five in the North American population, and two in the Asian population. All articles are of high quality because of NOS score no less than 6 . The chief characteristics of the enrolled materials are detailed in Table 1. 


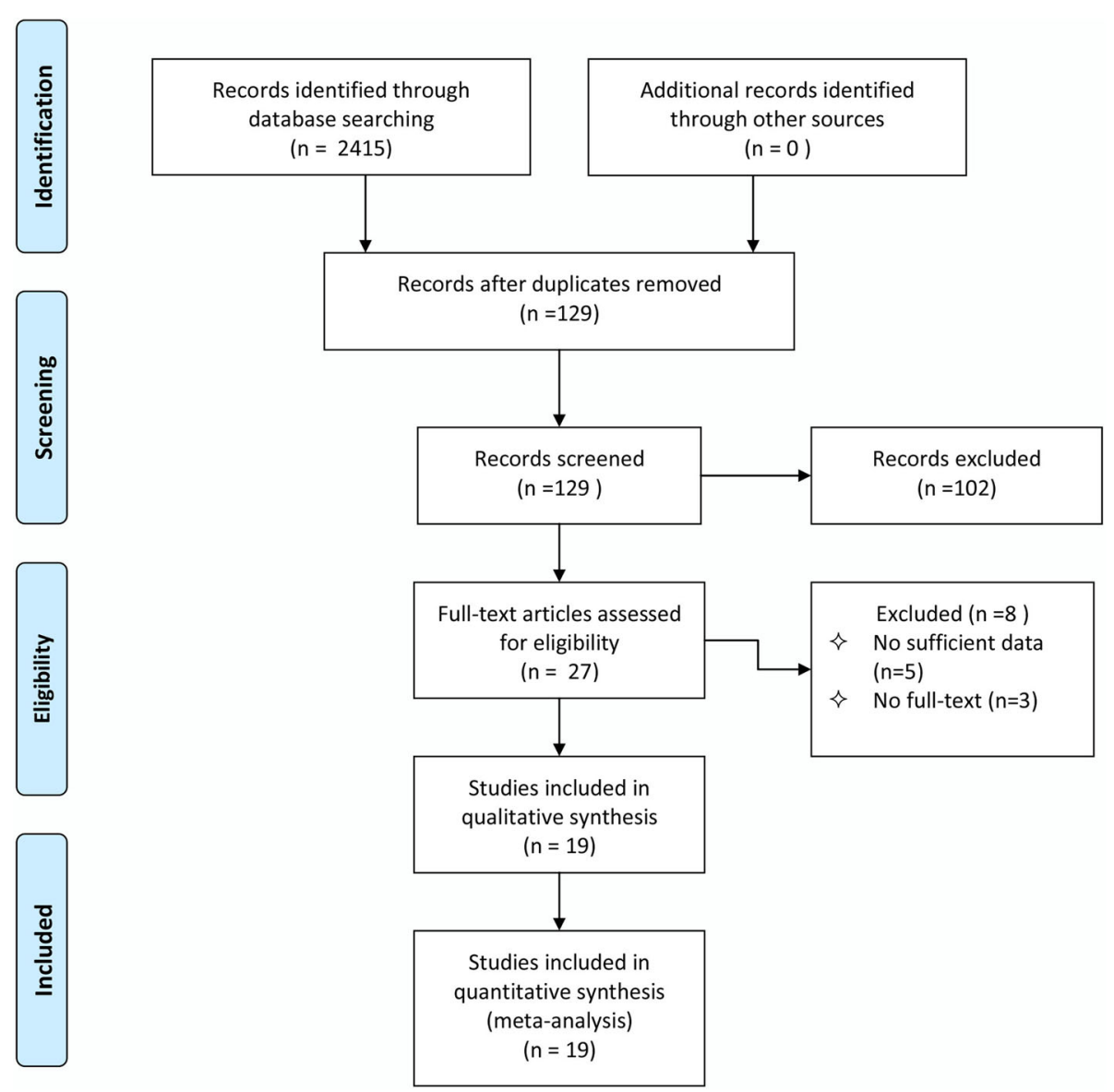

Fig. 1 Flow chart of search strategy and study selection

\section{Relationship between hypothyroidism and breast cancer risk}

There were 19 studies reported the relationship between hypothyroidism and breast cancer risk. With obvious heterogeneity $\left(I^{2}=78.2 \%, p=0.000\right)$ among these studies, so a random effect model was used for assessment. The pooled analysis suggested that was not related to the risk of breast cancer (OR 0.90, 95\% CI 0.77-1.03, $P<0.001)$ (Fig. 2).

\section{Subgroup analysis of hypothyroidism and risk of breast cancer}

To further explore the relationship between hypothyroidism and breast cancer risk, subgroup analysis was conducted from three aspects: study type, population distribution, and follow-up time. The results of subgroup analysis were shown in Table 2 . In the European subgroup, we observed that patients with hypothyroidism have a lower risk of breast cancer (OR $0.93,95 \%$ CI $0.88-0.99, P<0.001)$. In the subgroup with a follow-up date of more than four years, patients with hypothyroidism can reduce the risk of breast cancer, with borderline significance (OR 0.96, 95\% CI 0.91-1.00,
$P<0.001)$. In other subgroups, we found that hypothyroidism was not related to the risk of breast cancer.

\section{Relationship between thyroid hormone replacement therapy and breast cancer risk}

A total of 10 studies reported the relationship between the use of thyroid hormone replacement therapy and the risk of breast cancer $[4,8,9,15,17,21,23,25,26]$. As obvious heterogeneity observed, the fixed-effect model was used(I $\left.{ }^{2}=86.3 \%, p=0.000\right)$. The result suggested that patients who received thyroid hormone replacement therapy was not related to the risk of breast cancer $(\mathrm{OR}=0.87,95 \%$ CI 0.65-1.09; $P<0.001)$ (Fig. 3).

\section{Publication bias}

Figure $4 \mathrm{a}$ shows the results of publication bias for the relationship between hypothyroidism and breast cancer risk, which were evaluated by funnel plots and Eggers test. The Begg test $(P r=0.529)$ and the Egger test $(P=$ 0.892 ) were used to detecting publication bias showed that there was no possibility of publication bias. As shown in Fig. 4b, there were no publication biases in the 
Table 1 Main characteristics of the included studies in our-analysis

\begin{tabular}{|c|c|c|c|c|c|c|c|}
\hline Study & Year & Region & Sample & $\begin{array}{l}\text { Median/Mean age } \\
\text { (years) }\end{array}$ & $\begin{array}{l}\text { Follow-up } \\
\text { (years) }\end{array}$ & $\begin{array}{l}\text { Study } \\
\text { design }\end{array}$ & NOS \\
\hline Adami & 1978 & Sweden & 358 & 64 & 1 & Case-control & 7 \\
\hline Kalache & 1982 & UK & 2352 & NA & 11 & Case-control & 6 \\
\hline Hoffman & 1984 & Sweden & 1665 & 47.2 & 21.9 & Cohort & 8 \\
\hline Brinton & 1984 & USA & 2612 & NA & 4 & Case-control & 7 \\
\hline Moseson & 1993 & Canada & 1101 & 54 & 4 & Case-control & 7 \\
\hline Smyth & 1996 & Ireland & 400 & $57.2 \pm 1.4$ & 1 & Case-control & 7 \\
\hline Shering & 1996 & Ireland & 350 & NA & NA & Case-control & 7 \\
\hline Talamini & 1997 & Italy & 5157 & 55 & 3 & Case-control & 7 \\
\hline Simon & 2002 & USA & 9257 & NA & 4 & Case-control & 6 \\
\hline Turken & 2003 & Prague & 250 & 63 & 4 & Case-control & 6 \\
\hline Kuijpens & 2005 & Netherlands & 2775 & 50.5 & 9 & Cohort & 8 \\
\hline Cristofanilli & 2005 & USA & 2224 & $51.6 \pm 12.6$ & 3 & Case-control & 6 \\
\hline Sandhu & 2009 & Canada & 179,462 & $74.9 \pm 7$ & 10 & Cohort & 8 \\
\hline Hellevik & 2009 & Norwegian & 29,691 & $\geq 20$ & 9 & Cohort & 7 \\
\hline Ditsch & 2010 & Germany & 130 & $58.6 \pm 13.5$ & NA & Case-control & 7 \\
\hline Grani & 2012 & Italy & 380 & 59 & 5 & Case-control & 7 \\
\hline Søgaard & 2016 & Danish & 61,873 & 71 & 35 & Cohort & 7 \\
\hline Weng & 2018 & USA & 103,466 & 53.3 & NA & Case-control & 8 \\
\hline Kim & 2019 & Korea & 67,416 & $\geq 40$ & 4 & Cohort & 8 \\
\hline
\end{tabular}

\begin{tabular}{|c|c|c|}
\hline \multirow{2}{*}{$\begin{array}{l}\text { Study } \\
\text { ID }\end{array}$} & \multirow[b]{2}{*}{ ES $(95 \% \mathrm{Cl})$} & \multirow{2}{*}{$\begin{array}{l}\% \\
\text { Weight }\end{array}$} \\
\hline & & \\
\hline Adami (1978) & $1.00(0.14,7.18)$ & 0.14 \\
\hline Kalache (1982) & $0.80(0.31,2.03)$ & 2.01 \\
\hline Hoffman (1984) & $0.90(0.60,1.20)$ & 7.94 \\
\hline Brinton (1984) & $1.04(0.84,1.29)$ & 9.67 \\
\hline Moseson (1993) & $1.06(0.64,1.74)$ & 4.03 \\
\hline Smyth (1996) & $1.51(0.25,9.12)$ & 0.09 \\
\hline Shering (1996) & $3.41(0.65,17.84)$ & 0.02 \\
\hline Talamini (1997) & $0.72(0.39,1.33)$ & 4.97 \\
\hline Simon (2002) & $0.89(0.78,1.01)$ & 12.20 \\
\hline Turken (2003) & $6.17(0.33,115.94)$ & 0.00 \\
\hline Kuijpens (2005) & $2.30(1.20,4.60)$ & 0.58 \\
\hline Cristofanilli (2005) & $0.43(0.33,0.57)$ & 12.10 \\
\hline Sandhu (2009) & $0.99(0.92,1.07)$ & 12.88 \\
\hline Hellevik (2009) & $1.20(0.67,2.16)$ & 2.55 \\
\hline Ditsch (2010) & $0.86(0.29,2.53)$ & 1.26 \\
\hline Grani (2012) & $0.58(0.25,1.36)$ & 3.98 \\
\hline Sogaard (2016) & $0.94(0.88,1.00)$ & 13.08 \\
\hline Weng (2018) & $1.19(1.02,1.40)$ & 10.52 \\
\hline Kim (2019) & $0.74(0.28,2.01)$ & 1.99 \\
\hline Overall $(1-$ squared $=78.2 \%, p=0.000)$ & $0.90(0.77,1.03)$ & 100.00 \\
\hline \multicolumn{3}{|l|}{ NOTE: Weights are from random effects analysis } \\
\hline $\begin{array}{c}1 \\
-116\end{array}$ & & \\
\hline
\end{tabular}

Fig. 2 Relationship between hypothyroidism and breast cancer risk 
Table 2 Stratiedanalysis of the relationship between hypothyroidism and breast cancer risk

\begin{tabular}{|c|c|c|c|c|c|c|}
\hline \multirow[t]{2}{*}{ Variable } & \multirow{2}{*}{$\begin{array}{l}\text { No.of } \\
\text { studies }\end{array}$} & \multirow[t]{2}{*}{ OR(95\%Cl) } & \multirow[t]{2}{*}{$P$} & \multicolumn{2}{|c|}{ Heterogeneity } & \multirow{2}{*}{$\begin{array}{l}\text { Model } \\
\text { used }\end{array}$} \\
\hline & & & & $\bar{P}$ & $P_{h}$ & \\
\hline \multicolumn{7}{|l|}{ Region } \\
\hline Europe & 12 & $0.93(0.88-0.99)$ & $<0.001$ & 0 & 0.877 & Fixed \\
\hline North America & 5 & $0.86(0.60-1.11)$ & $<0.001$ & $93.8 \%$ & 0 & Randomed \\
\hline Asia & 2 & $1.17(0.98-1.35)$ & $<0.001$ & 0 & 0.319 & Fixed \\
\hline \multicolumn{7}{|l|}{ Study design } \\
\hline Case-control & 13 & $0.85(0.62-1.09)$ & $<0.001$ & $80.4 \%$ & 0 & Randomed \\
\hline Cohort & 6 & $0.96(0.91-1.01)$ & $<0.001$ & 0 & 0.517 & Fixed \\
\hline \multicolumn{7}{|l|}{ Follow-up date } \\
\hline$>4$ & 7 & $0.96(0.91-1.00)$ & $<0.001$ & 0 & 0.435 & Fixed \\
\hline$\leq 4$ & 9 & $0.80(0.54-1.07)$ & $<0.001$ & $81.0 \%$ & 0 & Randomed \\
\hline
\end{tabular}

Study

ID
$\%$

ES $(95 \% \mathrm{Cl})$

Weight

\begin{tabular}{llc}
\hline Hoffman (1984) & $0.90(0.60,1.20)$ & 12.99 \\
Kuijpens (2005) & $3.20(1.00,10.70)$ & 0.21 \\
Sandhu (2009) & $0.99(0.92,1.07)$ & 16.71 \\
Ditsch (2010) & $0.86(0.29,2.53)$ & 3.19 \\
Cristofanilli (2005) & $0.43(0.33,0.57)$ & 16.23 \\
Simon (2002) & $0.96(0.78,1.19)$ & 14.88 \\
Moseson (1993) & $1.06(0.64,1.74)$ & 8.32 \\
Brinton (1984) & $1.04(0.84,1.29)$ & 14.50 \\
Adami (1978) & $1.00(0.14,7.18)$ & 0.39 \\
Weng (2018) & $0.80(0.54,1.18)$ & 12.58 \\
Overall (I-squared $=86.3 \%, p=0.000)$ & $0.87(0.65,1.09)$ & 100.00 \\
NOTE: Weights are from random effects analysis & & \\
\hline
\end{tabular}

Fig. 3 Relationship between thyroid hormone replacement therapy and breast cancer risk 


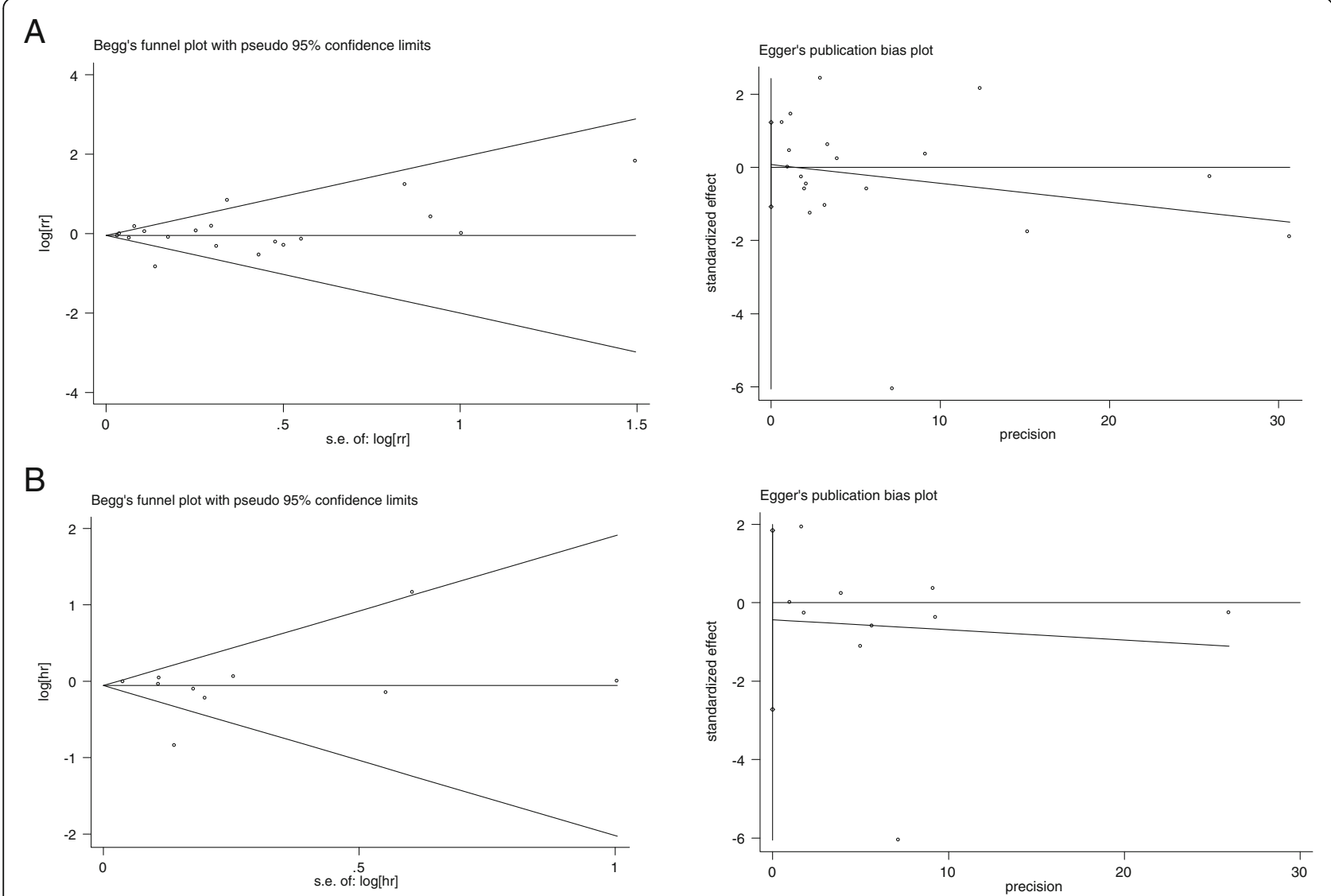

Fig. 4 Publication bias assessment a hypothyroidism; $\mathbf{b}$ thyroid hormone replacement therapy

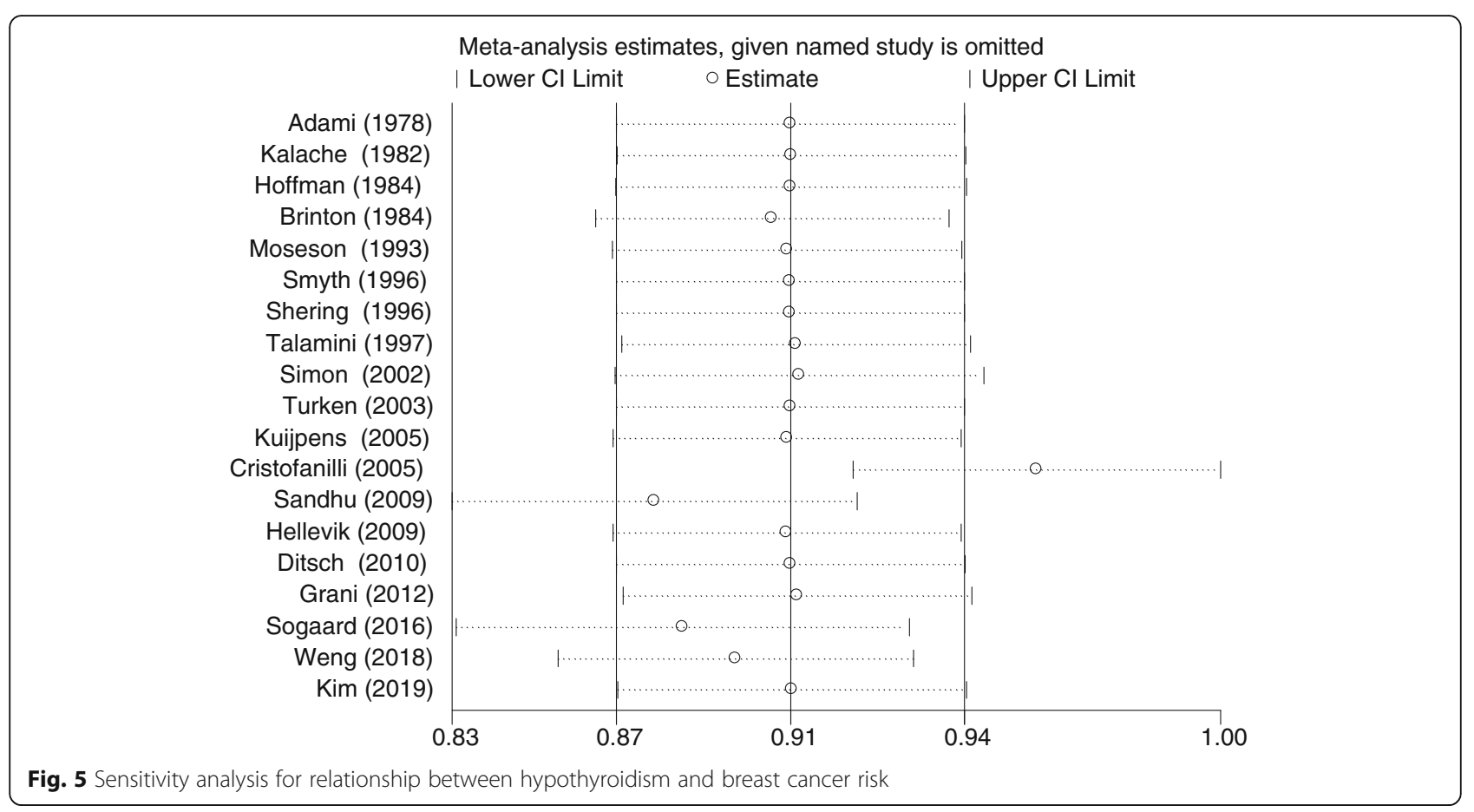


10 articles on the study of thyroid hormone replacement therapy. The Egger test was $P=0.672$, and the Begg test was $\operatorname{Pr}=0.858$.

\section{Sensitivity analysis}

The results of sensitivity analysis are generally stable, and the primary source of heterogeneity is in the research of Cristofanilli et al. [23].(Fig. 5). So we excluded the literature of Cristofanilli and analyzed the other studies. The results revealed that the hypothyroidism could reduce the risk of breast cancer was borderline significant (OR:0.96 95\%CI:0.92-1.00, $P<0.001$ ), and there was no heterogeneity $\left(\mathrm{I}^{2}=0, P=0.577\right)$.

\section{Discussion}

More than 100 years ago, Beatson et al. used thyroid extracts to treat patients with metastatic advanced breast cancer. The condition was significantly alleviated, sparking interest in exploring the relationship between thyroid and breast cancer [29]. Subsequently, a prospective study enrolled 2775 women, and 61 women with earlier diagnosis of hypothyroidism observed the occurrence of breast cancer during follow-up showed that low serum free thyroxine levels increased the risk of breast cancer [8]. In 2016, a prospective cohort study of 61,873 women with hypothyroidism and 80,343 hyperthyroidism found that hypothyroidism slightly reduced the risk of breast cancer [10]. However, a prospective cohort study of 89,731 women with autoimmune hypothyroidism and 89,731 women with normal thyroid function indicated that autoimmune hypothyroidism was not associated with breast cancer risk [25]. Besides, some animal experiments also reflect the relationship between the two [30, 31]. Animal experiments by López Fontana et al. found that hypothyroidism mice inhibit the development of breast cancer and promote the apoptosis of breast cancer cells due to the low expression of $\beta$-chain protein and activation of the apoptotic pathway on the tumour cell membrane [30]. Due to the inconsistency of the above conclusions, we performed a meta-analysis to evaluate the relationship between hypothyroidism and breast cancer risk.

A total of 19 studies were included in this metaanalysis, and the results showed that patients with hypothyroidism not related to the risk of breast cancer. However, there was significant heterogeneity among the included studies. After subgroup analysis and sensitivity analysis, we found that Cristofanilli's research may cause heterogeneity [23]. Cristofanilli's research is a retrospective study, and the diagnosis of hypothyroidism patients was based on the information recorded in the medical records, which may lead to the bias risk of misclassification and have a positive impact on the positive results of this study [23]. After excluding Cristofanilli's research, we found that patients with hypothyroidism had a lower risk of breast cancer with borderline significance [23]. The results of the meta-analysis are inconsistent with the findings of Hardefeldt et al. and Angelousi et al. [11, 12]. Perhaps because our study included more prospective studies and Asian population cohort study. In addition, we evaluated the risk of breast cancer in thyroid hormone replacement therapy and show that patients who received thyroid hormone replacement therapy was not related to the risk of breast cancer.

In the analysis of the European population, the results show that hypothyroidism may reduce the risk of breast cancer. We also found that patients with hypothyroidism can reduce the risk of breast cancer was borderline significance in the subgroup with more longer follow-up date. However, the relationship between the two was not observed in North American and Asian populations. The possible reasons for these disparities may be as follows. First, follow-up time may be the main contributors to this difference. A longer follow-up is required to demonstrate the relationship between hypothyroidism and breast cancer risk. In the meta-analysis, five studies provided North American population data, and two reported Asian population data. However, only one of seven non-European studies' follow-up time for more than 4 years. Second, the differences may be attributed to different ethnicities sharing different gene-gene and gene-environmental backgrounds. Third, social and environmental factors are another critical cause for this difference. With these in mind, our findings suggest that hypothyroidism may reduce the risk of breast cancer only in the European population and more large-scale, high-quality, long-term prospective cohort studies are still needed to study on different human populations.

The following may explain the potential relationship between hypothyroidism and the risk of breast cancer. Healthy mammary epithelial cells can express a large number of $\mathrm{T} 3$ receptors, and breast cancer cells have a similar ability to bind to T3 [32]. T3 has an estrogenlike effect that promotes the growth of mammary gland lobes and stimulates normal breast tissue differentiation $[33,34]$. Therefore, T3 can mimic the effect of estrogen on the proliferation of breast cancer cells. When the concentration of T3 is low in vivo, it may inhibit the proliferation of breast cancer cells. Hypothyroidism may reduce the risk of breast cancer by affecting T3 concentration.

Some basic experiments support this theory. In 2002, Gonzalez-Sancho et al. studied the relationship between T3 and breast cancer [35]. It was found that there is an over-expressed T1 gene in human breast cancer cells, and T3 inhibits the proliferation of mammary epithelial cells by inhibiting the expression of cyclin D1 and T1, thereby inhibiting the proliferation of breast cancer cells 
[35]. After that, Martinez-Iglesias found that hypothyroidism can inhibit the growth of breast cancer cells [31]. In 2010, Tosovic conducted a prospective study of T3 levels associated with breast cancer risk and found that T3 levels in postmenopausal women were positively correlated with breast cancer risk in a doseresponse manner [36]. Therefore, we suspect that hypothyroidism through lower levels of T3 could reduce the incidence of breast cancer. Our meta-analysis results also confirm the above conjecture.

However, this conclusion needs to be taken with caution, as this study has several limitations. First, the studies that have been included do not adjust for important risk factors for breast cancer. Second, in subgroup analysis, for example, there are only two articles in Asian studies, and we should be cautious about the results of Asian analysis. Third, the results of this meta-analysis indicate that there is a large heterogeneity between studies. Fourth, follow-up time at different endpoints cannot be uniform. Finally, publication bias cannot be avoided entirely.

\section{Conclusion}

Hypothyroidism may reduce the risk of breast cancer in the European population, and no significant correlation was observed between hypothyroidism and breast cancer risk in non-European populations. Furthermore, there was no obvious correlation between thyroid hormone replacement therapy and breast cancer risk. It is necessary to conduct a large sample size, strictly controlled prospective study of hypothyroidism patients further to demonstrate the relationship between hypothyroidism and breast cancer risk.

\section{Abbreviations}

OR: Odd ratios; Cl: Confidence intervals; NOS: Newcastle-Ottawa Scale

\section{Acknowledgements}

Not applicable.

\section{Authors' contributions}

Study design: BW, ZL, RL, YH and TL; Data extraction: BW, ZL, TL and YH; Data analysis: BW, ZL, RL,and YH; Manuscript writing: BW and RL; Manuscript edition: $\mathrm{RL}$ and $\mathrm{YH}$. All authors have read and approved the manuscript.

\section{Funding}

No sources of funding were used to conduct this study or prepare this letter.

\section{Availability of data and materials}

All the published articles and data were available online.

Ethics approval and consent to participate

Not applicable.

\section{Consent for publication}

Not applicable.

\section{Competing interests}

None.

\section{Author details}

${ }^{1}$ School of Clinical Medicine, Weifang Medical University, Weifang 261053, China. ${ }^{2}$ Department of Oncology, Affiliated Hospital of Weifang Medical University, Weifang 261031, China. ${ }^{3}$ School of Basic Medicine, Weifang Medical University, Weifang 261053, China.

Received: 7 December 2019 Accepted: 28 July 2020

Published online: 06 August 2020

\section{References}

1. Siegel RL, Miller KD, Jemal A. Cancer statistics, 2018. CA Cancer J Clin. 2018; 68(1):7-30. https://doi.org/10.3322/caac.21442.

2. Praestegaard C, Kjaer SK, Andersson M, Steding-Jensen M, Frederiksen $K_{t}$ Mellemkjaer $\mathrm{L}$. Risk of skin cancer following tamoxifen treatment in more than 16,000 breast cancer patients: a cohort study. Breast cancer. 2016;23(6): 908-16. https://doi.org/10.1007/s12282-015-0660-5.

3. Mittra I, Hayward JL. Hypothalamic-pituitary-thyroid axis in breast cancer. Lancet. 1974;1 (7863):885-9. https://doi.org/10.1016/s0140-6736(74)90344-4.

4. Adami HO, Rimsten A, Thoren L, Vegelius J, Wide L. Thyroid disease and function in breast cancer patients and non-hospitalized controls evaluated by determination of TSH, T3, rT3 and T4 levels in serum. Acta Chir Scand. 1978;144(2):89-97.

5. Dargent $M$, Berger $M$, Lahneche B. Thyroid function in patients with Cancer of the breast. Acta. 1964;20:1425-30.

6. Mustacchi P, Greenspan F. Thyroid supplementation for hypothyroidism. An latrogenic cause of breast cancer? JAMA. 1977;237(14):1446-7.

7. Kapdi CC, Wolfe JN. Breast cancer. Relationship to thyroid supplements for hypothyroidism. JAMA. 1976;236(10):1124-7. https://doi.org/10.1001/jama. 236.10.1124.

8. Kuijpens JL, Nyklictek I, Louwman MW, Weetman TA, Pop VJ, Coebergh JW. Hypothyroidism might be related to breast cancer in post-menopausal women. Thyroid. 2005;15(11):1253-9. https://doi.org/10.1089/thy.2005.15. 1253.

9. Weng CH, Chen YH, Lin CH, Luo X, Lin TH. Thyroid disorders and breast cancer risk in Asian population: a nationwide population-based case-control study in Taiwan. BMJ Open. 2018;8(3):e020194. https://doi.org/10.1136/ bmjopen-2017-020194.

10. Sogaard M, Farkas DK, Ehrenstein V, Jorgensen JO, Dekkers OM, Sorensen HT. Hypothyroidism and hyperthyroidism and breast cancer risk: a nationwide cohort study. Eur J Endocrinol. 2016;174(4):409-14. https://doi. org/10.1530/EJE-15-0989.

11. Angelousi AG, Anagnostou VK, Stamatakos MK, Georgiopoulos GA, Kontzoglou KC. Mechanisms in endocrinology: primary HT and risk for breast cancer: a systematic review and meta-analysis. Eur J Endocrinol. 2012; 166(3):373-81. https://doi.org/10.1530/EJE-11-0838.

12. Hardefeldt PJ, Eslick GD, Edirimanne S. Benign thyroid disease is associated with breast cancer: a meta-analysis. Breast Cancer Res Treat. 2012;133(3): 1169-77. https://doi.org/10.1007/s10549-012-2019-3.

13. Stang A. Critical evaluation of the Newcastle-Ottawa scale for the assessment of the quality of nonrandomized studies in meta-analyses. Eur J Epidemiol. 2010;25(9):603-5. https://doi.org/10.1007/s10654-010-9491-z.

14. Kalache A, Vessey MP, McPherson K. Thyroid disease and breast cancer: findings in a large case-control study. Br J Surg. 1982;69(7):434-5. https:// doi.org/10.1002/bjs.1800690731.

15. Hoffman DA, McConahey WM, Brinton LA, Fraumeni JF Jr. Breast cancer in hypothyroid women using thyroid supplements. JAMA. 1984;251(5):616-9.

16. Brinton LA, Hoffman DA, Hoover R, Fraumeni JF Jr. Relationship of thyroid disease and use of thyroid supplements to breast cancer risk. J Chronic Dis. 1984;37(12):877-93. https://doi.org/10.1016/0021-9681(84)90062-6.

17. Moseson M, Koenig KL, Shore RE, Pasternack BS. The influence of medical conditions associated with hormones on the risk of breast cancer. Int J Epidemiol. 1993;22(6):1000-9. https://doi.org/10.1093/ije/22.6.1000.

18. Shering SG, Zbar AP, Moriarty M, McDermott EW, O'Higgins NJ, Smyth PP. Thyroid disorders and breast cancer. Eur J Cancer Prevent. 1996;5(6):504-6.

19. Smyth PP, Smith DF, McDermott EW, Murray MJ, Geraghty JG, O'Higgins NJ. A direct relationship between thyroid enlargement and breast cancer. J Clin Endocrinol Metab. 1996;81(3):937-41. https://doi.org/10.1210/jcem.81.3. 8772554.

20. Talamini R, Franceschi S, Favero A, Negri E, Parazzini F, La Vecchia C. Selected medical conditions and risk of breast cancer. Br J Cancer. 1997; 75(11):1699-703. https://doi.org/10.1038/bjc.1997.289. 
21. Simon MS, Tang MT, Bernstein L, Norman SA, Weiss L, Burkman RT, Daling JR, Deapen D, Folger SG, Malone K, Marchbanks PA, McDonald JA, Strom BL, Wilson $\mathrm{HG}$, Spirtas R. Do thyroid disorders increase the risk of breast cancer? Cancer Epidemiol Biomarkers Prevent. 2002;11(12):1574-8.

22. Turken O, Narln Y, Demlrbas S, Onde ME, Sayan O, Kandemlr EG, Yaylac IM, Ozturk A. Breast cancer in association with thyroid disorders. Breast Cancer Res. 2003;5(5):R110-3. https://doi.org/10.1186/bcr609.

23. Cristofanilli M, Yamamura Y, Kau SW, Bevers T, Strom S, Patangan M, Hsu L, Krishnamurthy S, Theriault RL, Hortobagyi GN. Thyroid hormone and breast carcinoma. Primary hypothyroidism is associated with a reduced incidence of primary breast carcinoma. Cancer. 2005;103(6):1122-8. https://doi.org/10. 1002/cncr.20881.

24. Hellevik LR, Vierendeels J, Kiserud T, Stergiopulos N, Irgens F, Dick E, Riemslagh K, Verdonck P. An assessment of ductus venosus tapering and wave transmission from the fetal heart. Biomech Model Mechanobiol. 2009; 8(6):509-17. https://doi.org/10.1007/s10237-009-0155-4.

25. Sandhu MK, Brezden-Masley C, Lipscombe LL, Zagorski B, Booth GL. Autoimmune hypothyroidism and breast cancer in the elderly. Breast Cancer Res Treat. 2009;115(3):635-41. https://doi.org/10.1007/s10549-0080104-4.

26. Ditsch N, Liebhardt S, Von Koch F, Lenhard M, Vogeser M, Spitzweg C, Gallwas J, Toth B. Thyroid function in breast cancer patients. Anticancer Res. 2010;30(5):1713-7.

27. Grani G, Dicorato P, Dainelli M, Coletta I, Calvanese A, Del Sordo M, De Cesare A, Di Matteo FM, D'Andrea V, Fumarola A. Thyroid diseases in women with breast cancer. La Clin Terapeut. 2012;163(6):e401-4.

28. Kim EY, Chang Y, Lee KH, Yun JS, Park YL, Park CH, Ahn J, Shin H, Ryu S. Serum concentration of thyroid hormones in abnormal and euthyroid ranges and breast cancer risk: a cohort study. Int J Cancer. 2019;145(12): 3257-66. https://doi.org/10.1002/ijc.32283.

29. Beatson GT. On The Treatment Of Inoperable Cases Of Carcinoma Of The Mamma: Suggestions For A New Method Of Treatment, With Illustrative Cases.1. Lancet. 148(3802):104-7.

30. Lopez Fontana CM, Zyla LE, Santiano FE, Sasso CV, Cuello-Carrion FD, Pistone Creydt V, Fanelli MA, Caron RW. Hypothyroidism reduces mammary tumor progression via Beta-catenin-activated intrinsic apoptotic pathway in rats. Histochem Cell Biol. 2017;147(6):759-69. https://doi.org/10.1007/s00418017-1544-x

31. Martinez-Iglesias O, Garcia-Silva S, Regadera J, Aranda A. Hypothyroidism enhances tumor invasiveness and metastasis development. PLoS One. 2009; 4(7):e6428. https://doi.org/10.1371/journal.pone.0006428.

32. Nogueira CR, Brentani MM. Triiodothyronine mimics the effects of estrogen in breast cancer cell lines. J Steroid Biochem Mol Biol. 1996;59(3-4):271-9. https://doi.org/10.1016/s0960-0760(96)00117-3.

33. Alyusuf RH, Matouq JA, Taha S, Wazir JF. The pattern of expression and role of triiodothyronine (T3) receptors and type I $5^{\prime}$-deiodinase in breast carcinomas, benign breast diseases, lactational change, and normal breast epithelium. Appl Immunohistochem Mol Morphol. 2014;22(7):518-23. https://doi.org/10.1097/PAl.0b013e3182a20917.

34. Pereira B, Rosa LF, Safi DA, Bechara EJ, Curi R. Control of superoxide dismutase, catalase and glutathione peroxidase activities in rat lymphoid organs by thyroid hormones. J Endocrinol. 1994;140(1):73-7. https://doi.org/ 10.1677/joe.0.1400073

35. Gonzalez-Sancho JM, Figueroa A, Lopez-Barahona M, Lopez E, Beug H Munoz A. Inhibition of proliferation and expression of T1 and cyclin D1 genes by thyroid hormone in mammary epithelial cells. Mol Carcinog. 2002; 34(1):25-34. https://doi.org/10.1002/mc.10046.

36. Tosovic A, Bondeson AG, Bondeson L, Ericsson UB, Malm J, Manjer J. Prospectively measured triiodothyronine levels are positively associated with breast cancer risk in postmenopausal women. Breast Cancer Res. 2010; 12(3):R33. https://doi.org/10.1186/bcr2587.

\section{Publisher's Note}

Springer Nature remains neutral with regard to jurisdictional claims in published maps and institutional affiliations.

Ready to submit your research? Choose BMC and benefit from:

- fast, convenient online submission

- thorough peer review by experienced researchers in your field

- rapid publication on acceptance

- support for research data, including large and complex data types

- gold Open Access which fosters wider collaboration and increased citations

- maximum visibility for your research: over $100 \mathrm{M}$ website views per year

At BMC, research is always in progress.

Learn more biomedcentral.com/submissions 